\title{
PARTICIPATION OF RURAL WOMEN IN EXPLOITATION OF NON-TIMBER FOREST PRODUCTS AS A MEANS OF SUSTAINABLE LIVELIHOOD IN SOUTHWESTERN NIGERIA
}

\author{
O.A. BAMIWUYE ${ }^{1}$, B.O. ADISA ${ }^{2}$, K.A. ADELOYE ${ }^{2}$, M. FAMAKINWA ${ }^{2, *}$ \\ *E-mail: famakinwamichael2013@gmail.com
}

Received: Dec. 09, 2019. Revised: Jan. 27, 2020. Accepted: Jan. 31, 2020. Published online: Mar. 06, 2020

\begin{abstract}
The study examined the participation of rural women in exploitation of non-timber forest products (NTFPs), as a means of sustainable livelihood in Southwestern Nigeria. A number of 320 respondents were interviewed through pre-tested structured interview schedule in the four purposively selected forest reserves using a multistage sampling procedure. Data collected were presented using appropriate descriptive and inferential statistics. The mean age and mean year of experience in NTFPs exploitation were $40.9 \pm 11.5$ years and16.4 \pm 3.4 years, respectively. NTFPs participated by the respondents in the study area were palm fruits, vegetables, snails and fire wood among others. Actor categories identify in the NTFPs business chain were collectors, processors, traders among others. In addition, majority of the respondents show willingness to continue in NTFPs exploitation irrespective of alternative livelihood. The findings revealed that age $(\mathrm{t}=2.39)$, number of
\end{abstract}

hours of collection per week $(\mathrm{t}=3.48)$, years of experience of NTFPs exploitation $(\mathrm{t}=-3.88)$ and external orientation $(t=2.20)$ of respondents significantly contributed to their participation in NTFPs exploitation. The study concludes that participation in NTFPs exploitation by the respondents was moderate. It was recommended that more enlightenment programmes should be organized by relevant stakeholders for the rural women to create awareness on the income generation opportunities that abound in the NTFPs activities.

Keywords: socioeconomic variables; tropical forest; income generating activities; forest resources.

\section{INTRODUCTION}

In the last decade, there has been a growing recognition of adoption of livelihood approaches to development, especially in the rural areas of many

\footnotetext{
${ }^{1}$ Department of Agricultural Economics and Extension, Osun State University Osogbo Ejigbo Campus, Ejigbo, Osun State, Nigeria

2 Department of Agricultural Extension and Rural Development, Obafemi Awolowo University lle-lfe, Nigeria
} 


\section{PARTICIPATION OF RURAL WOMEN IN EXPLOITATION OF NON-TIMBER FOREST PRODUCTS}

developing countries (Akanni, 2013; Adisa and Alao, 2011; Ogunbanjo and Aina, 2013). Research efforts at alleviating rural poverty in developing countries have identified what communities can do to improve rural livelihoods in a sustainable manner. One of such ways, which has begun to receive more attention globally, is utilization of Non-Timber Forest Products (NTFPs) (Bisong and Ajake, 2001; Dovie, 2003; Shackleton and Shackleton, 2004; Jimoh et al., 2012, Angoni, 2015). Non-timber forest products (NTFPs) refer to natural resources collected from forests, apart from sawn timber, and these include other wooded land and trees outside forest reserves (FAO, 2012). There are several types of NTFPs for exploitation in Nigeria and these include a wide range of edibles and non-edibles, such as fruits, seeds, leaves, nuts, bush meat, roots, tubers, fibres, resins, latex, sticks, ropes, and construction materials like bamboos and rattans among others (Adisa and Alao, 2011; Akanni, 2013; Sulaimon, 2016). Exploitation of such natural resources increases the range of income generating options for rural women, especially in developing countries, including Nigeria (Amusa et al., 2012; Fernande and Ghislaine, 2014).

Traditionally, households, especially rural women living around forest areas collect various NTFPs in Nigeria and such households are, therefore, dependent on the continued growth of forest products. Collection and selling of NTFPs is therefore not only an important source of income by increasing their purchasing power, but also provides medicine and contributes to food security in the household (Chikamai and Kagombe, 2002; Jimoh et al., 2012). Rural women have vast indigenous knowledge on the medicinal, nutritional, spiritual and economic uses of a wide range of NTFPs. Hence, they are increasingly taking advantage of such products because of the immense contributions to their subsistence, daily life, their welfare and in general the development of rural economies (Ellis and Allison 2004; Olaniyi et al., 2013).

Exploitation of NTFPs is usually less destructive than timber harvesting, and offers good opportunities for improving livelihoods, as NTFPs are generally easily accessible to the rural poor and little capital investment is needed for collection, processing and marketing (Ellis and Allison, 2004). Consequently, trading NTFPs potentially offers a means of concurrently achieving both conservation and development goals (Olaniyi et al., 2013; Suleiman et. al., 2017).

During the 1960s and 1979s, forest products earned large amounts of foreign exchange and the sector was ranked highest in employment generation in Nigeria (National Bureau of Statistics, 2014). NTFPs are rapidly growing and as such the importance goes beyond meeting basic needs of food. Despite the importance of NTFPs for rural livelihoods, as well as its good potentials for socio-economic 


\section{O.A. BAMIWUYE, B.O. ADISA, K.A. ADELOYE, M. FAMAKINWA}

development of Nigeria, the sector has generally been overlooked by policy makers. Until in the last decade, forestry Departments have not paid much attention to the potentials of NTFPs resources (Biswas and Chowdhury, 2007; Vantomme et al., 2002). The available literature on exploitation of NTFPs have focused on prevalence and collection (Jimoh et al., 2012; Jimoh and Haruna, 2007; Aiyeloja and Ajewole, 2006; Suleiman et al., 2017) and conservation strategies of forest products (Jimoh et al., 2012), as well as the importance of NTFPs (Aiyeloja and Ajewole, 2006). Evidence is scarce on the level of participation of rural women in the exploitation of NTFPs, as a means of livelihood in the study area. In the light of the above, the study described the socioeconomic characteristics of the respondent: identified actor categories in NTFPs exploitation along business chain; examined the willingness of respondents to continue the exploitation of NTFPs and determined respondents' level of participation in the exploitation of NTFPs.

\section{Hypothesis}

There is no significant relationship between socioeconomic variables of respondents and their participation in exploitation of NTFPs.

\section{MATERIAL AND METHODS}

The study was carried out between May 2018 and December 2018 in the forest communities in the selected States in Southwestern Nigeria. The population for the study comprises all rural women living, who engage in the collection of NTFPs. The major forest reserves are Omo in Ogun State, Shasha in Osun State and Oluwa and Akure-Ofosu in Ondo State. Omo forest reserve (OFR) is located between latitudes $6^{\circ} 35^{\prime}-7^{\circ} 05^{\prime} \mathrm{N}$ and longitudes $4^{\circ} 19^{\prime}-4^{\circ} 40^{\prime} \mathrm{E}$ in the Ijebu East and North Local Government Areas of Ogun State, Southwestern Nigeria. The Reserve covers an area of about 130,500 ha forming common boundaries with Osun, Ago-Owu and Shasha Forest Reserves in Osun State and Oluwa Forest Reserve in Ondo State (Ogunjemite and Olaniyi, 2012). The study design was crosssectional in nature and utilized multistage sampling procedure in selecting the sample.

At first stage, three out of six States in Southwestern Nigeria were purposively selected based on the size of the forest reserves. These States were Ogun, Osun and Ondo. In all, there are a total of 37 forest reserves in the three selected States (9 in Ogun, 11 in Osun and 17 in Ondo States). Each of the forests has some degree of encroachment. At the second stage, $10 \%$ of all the 37 forest reserves were selected and this translates to four forest reserves. In selecting the four forest reserves, the largest in each of the selected States was purposively selected. To make the selection to be proportional to the number in each State, and on the basis of forest reserve size, Oluwa and Akure-Ofosu were selected in Ondo State, Omo and Shasha Forest Reserves were selected from Ogun and Osun States, respectively. At the third stage $20 \%$ of the total number of communities in the forest reserves was randomly selected making a total of 32 communities across the three States. At the last stage, a total of 320 respondents 


\section{PARTICIPATION OF RURAL WOMEN IN EXPLOITATION OF NON-TIMBER FOREST PRODUCTS}

were randomly selected for interview. Validated and pre-tested interview schedule was used to collect quantitative data while focus group discussion guide was used to elicit qualitative information from the respondents. Data management and analysis were carried out using Stata 14. Descriptive statistics, such as frequency counts, percentages, means and standard deviation, were used to summarise the data while regression analysis.

The dependent variable is participation in exploitation of NTFPs. In order to capture this variable, respondents were asked to rate their extent of participation in each of the forest produce/products on a 4-point Likert type scale - Always (3), Sometimes (2), Rarely (1) and Never (0).

The mean plus or minus one standard deviation was used to classify the participation scores into three levels: low, moderate and high, as used by Famakinwa (2017) and Bamiwuye (2014). Level of participation was classified as low when the total participation score fell below the difference between the mean score and one unit of standard deviation. Participation in exploitation was at the high level when score was above the sum of the mean score and one unit of standard deviation, while at the medium level, participation score fell in between the two extremes (plus or minus one unit of standard deviation).

\section{RESULTS AND DISCUSSION}

\section{Socioeconomic characteristics of the respondents}

Results in Table 1 show that the mean age of the respondents was $40.9 \pm 11.5$ years, suggesting that substantial proportion of the respondents were in their middle ages, this indicates that many of the respondents were still active and agile; are expected to be found in productive enterprise that will contribute to livelihood; in addition, the mean years of experience of women who have been involved in the NTFP business was $13.5 \pm 4.6$ years. This implies that the NTFPs exploitation activities in the study area is stable, sustainable and dependable since these women have been in this business for a long time without quitting and that they have realized the great potentials of NTFPs as a means of livelihood in recent yrs. This is in agreement with the work of Raufu et al. (2012) in a study of economic analysis of rural women income from NTFPs in Ife South Local Government Area of Osun State, which stated that rural women have found NTFPs as alternative source of livelihood.

Furthermore, most $(82.8 \%)$ of the respondents claimed to be involved on part time basis, indicating that majority of the respondents have other means of survival aside NTFPs exploitation and that they engaged in NTFPs, as a means of augmenting their major source of livelihood. Majority (71.6\%) got their collection from cultivated forests, this could be as a results of danger and risk involved in natural forest exploitation. Also, majority $(91.2 \%)$ of the respondents had travelled out their communities in the last one year, indicating high external orientation, as they will be exposed to more 


\section{O.A. BAMIWUYE, B.O. ADISA, K.A. ADELOYE, M. FAMAKINWA}

information on how are things are done elsewhere with respect to NTFPs. The mean number of collection hrs spent by the respondents in any given week was $12.47 \pm 2.07$ hours on the NTFP business. More than half of the respondents $(52.2 \%)$ spent 10 hours or less in any given week to source for NTFPs. The implication of the finding is that women in the rural area dedicate bulk of their time on NTFP business for livelihood purpose.

Table 1 - Distribution of respondents by experience with exploitation of NTFPs $(n=320)$

\begin{tabular}{|c|c|c|}
\hline Variables & Frequency & Percentage \\
\hline \multicolumn{3}{|l|}{ Age (years) } \\
\hline \multicolumn{3}{|l|}{ Below 25} \\
\hline \multicolumn{3}{|l|}{$25-34$} \\
\hline \multicolumn{3}{|l|}{$35-44$} \\
\hline \multicolumn{3}{|l|}{45 and above } \\
\hline Mean and standard deviation & $40.9 \pm 11.5$ years & \\
\hline $\begin{array}{l}\text { Years of experience in exploiting NTFPs } \\
\text { Less than } 10 \text { yrs }\end{array}$ & 112 & 35.0 \\
\hline $10-19$ years & 110 & 34.4 \\
\hline 20 or more & 98 & 30.6 \\
\hline Mean \pm Standard deviation & $13.5 \pm 4.6$ years & \\
\hline \multicolumn{3}{|l|}{ Extent of exploitation of NTFPs } \\
\hline Full time & 44 & 13.8 \\
\hline Part time & 265 & 82.8 \\
\hline Seasonal/Contract & 11 & 3.4 \\
\hline \multicolumn{3}{|l|}{ Sources of NTFP collection } \\
\hline Natural forest & 91 & 28.4 \\
\hline Cultivated forest & 229 & 71.6 \\
\hline \multicolumn{3}{|l|}{ External orientation } \\
\hline Never travelled & 294 & 91.9 \\
\hline Travelled & 26 & 8.1 \\
\hline \multicolumn{3}{|l|}{ Number of collection hours per week (hrs) } \\
\hline 10 or below & 167 & 52.2 \\
\hline $11-19$ & 75 & 23.4 \\
\hline $20-29$ & 46 & 14.4 \\
\hline 30 or more & 32 & 10.0 \\
\hline Mean \pm Standard deviation & $12.47 \pm 2.07$ & \\
\hline
\end{tabular}

Source: Field survey, 2018

\section{Actor categories}

\section{in the NTFP business chain}

Result in Fig. 1 identified six categories of actors in the NTFP business chain. These actors were the collectors, the processors, the agents and the traders. Others were the wholesalers and the retailers. 


\section{PARTICIPATION OF RURAL WOMEN IN EXPLOITATION OF NON-TIMBER FOREST PRODUCTS}

The collectors are those who go and collect NTFP from forest; the processors are those who process/ produce the NTFP based products. The agents search out and/or organize the NTFP supply for other people in the NTFP value chain; they do not buy and sell, but work on commission or contract for a trader or other actor in the business chain. The traders both buy and sell NTFP, but don't sell directly to consumers.

The wholesalers sell NTFP to retailer/directly to consumers in bulk volume, while the retailers sell directly to the consumers. Results in Fig. 1 show that the collectors constitute more than half of the respondents in the actor categories comprising $52.2 \%$ in the NTFP business chain. Closely following the collectors in this chain were the wholesalers (39.4\%) and those who processed NTFPs for sale $(37.8 \%)$. While $37.2 \%$ were retailers in the primary actor categories, less than one-third $(28.1 \%)$ of the women were traders and the least in the category of actors in the business chain were the agents (13.4\%). This distribution of actor categories in the NTFP business chain further buttress the fact that rural women can engage in NTFPs in various ways to enhance their income. According to Ingram (2009), the relative income generated by NTFPs can differ greatly among actors in the chain.

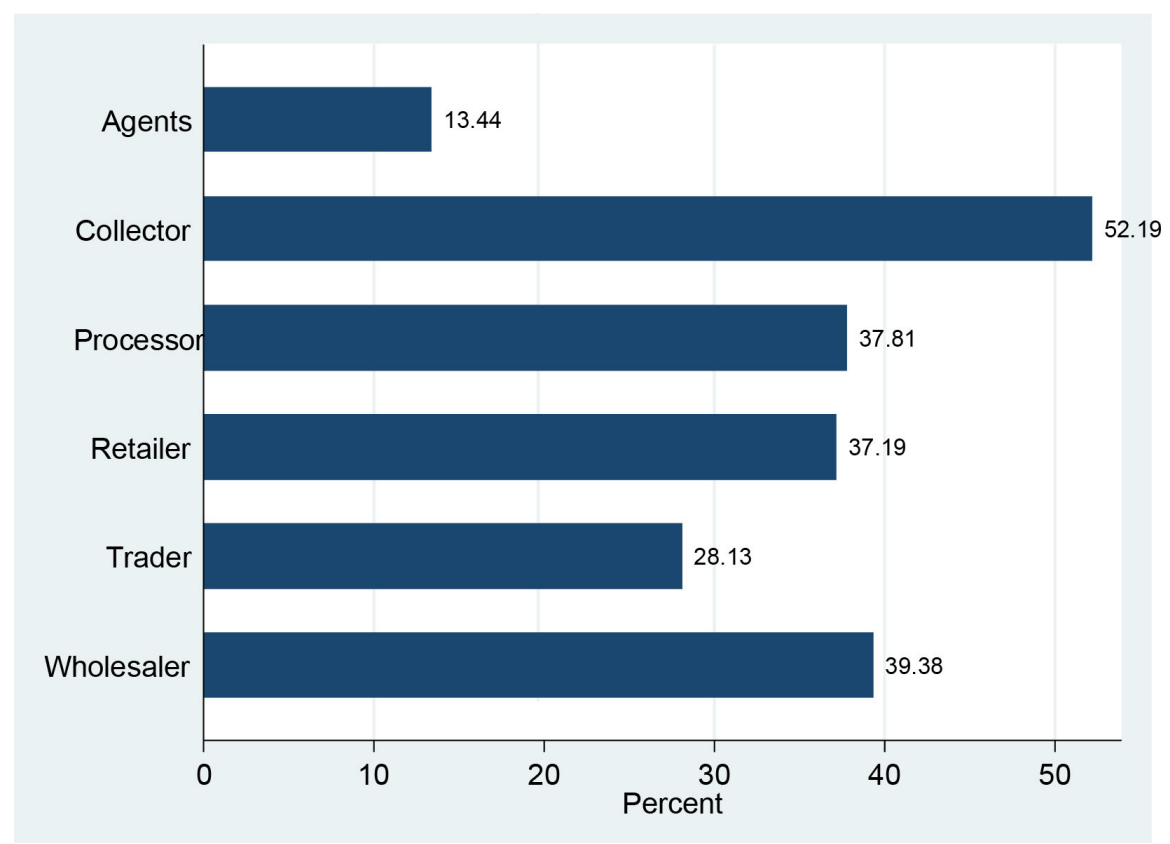

Source: Field survey, 2018

Figure 1 - Distribution of respondents by primary actor categories in the NTFP business chain 


\section{Participation in the exploitation of NTFPs}

Results in Table 2 showed that ranked mean in descending order of participation in NTFPs. Palm fruit (mean $=2.667$ ) ranked highest among NTFPs collected by the respondents. This is closely followed by Kolanut $($ mean $=2.359)$, Bitter Cola $($ mean $=$ 1.597), Vegetable (mean $=1.597)$, Snail (mean $=1.581)$, Firewood $($ mean $=1.494)$, Bushmeat $($ mean $=$ 1.447) in that order. This is because they are readily available, easy to get cheap and their benefits. For instance, Palm fruits, vegetables and snail are good sources of food this corroborate the finding of Vongkhamsao (2007), which established that NTFPs serve as important safety net or coping strategies for the rural poor in time of food scarcity. Also, Kolanut and Bitter Cola have high medicinal value, as indicated by some respondents in focus group discussion: "kolanut and bitter cola are used as stimulants and enhances good vision". This in line with the study of Andel (2006), who reported that majority of rural dwellers in developing countries use wild plants to meet some of their health and nutritional needs.

The five least gathered NTFPs in the study area were spring onion (Alubosa elewe), Asofeye (Rauvolla vomitora), shea butter, Isin and coffee. This result suggests that rural women are involved at the different levels of exploiting NTFPs particularly, those that offer great economic benefit.

\section{Level of participation in NTFP exploitation}

Results in Fig. 2 show the overall level of participation of the women in the exploitation of NTFPs in the forest communities. About $38.4 \%$ of the women have low level of participation in the exploitation of NTFPs, $31.9 \%$ moderately participate in the NTFP business, while $29.7 \%$ of the respondents have high participation level. This shows that at least $61.6 \%$ of the respondents were either moderately or highly involved in NTFPs as livelihood choice. This finding suggested that rural women participate at different levels of gathering NTFPs in the study locations.

Although not classified in terms of level of participation, Dishan et al. (2011), in a study of women's participation in non-timber forest products utilization in support zones of Gashaka Gumti national park, showed that $84 \%$ of women were involved in NTFP business.

Adisa and Alao (2011), in similar study among youth in Southwestern Nigeria, revealed that as many as $85 \%$ and $75.8 \%$ of the respondents always exploit Ocimum basilicum (Efirin) and Xylopia aethiopica (Eeru). Thus NTFPs exploitation has positive influence on livelihood of the rural women in the area. This is in agreement with the study of Carr and Hartl (2008) that Non-Timber Forest Products is a sector that offers great promise for women, therefore, for any poverty-reduction programme in Nigeria to succeed. Women should be 


\section{PARTICIPATION OF RURAL WOMEN IN EXPLOITATION OF NON-TIMBER FOREST PRODUCTS}

given greater opportunities to products so as to enhance their participate in exploitation of NTFP livelihood.

Table 2 - Distribution of respondents by their participation in gathering of NTFPs

\begin{tabular}{|c|c|c|}
\hline NTFPs & Mean score & Rank \\
\hline Palm fruit & 2.669 & 1 \\
\hline Kolanut & 2.359 & 2 \\
\hline Bitter cola & 1.603 & 3 \\
\hline Vegetable & 1.597 & 4 \\
\hline Snail & 1.581 & 5 \\
\hline Firewood & 1.494 & 6 \\
\hline Bush meat & 1.447 & 7 \\
\hline Mango/Orange fruit & 1.447 & 7 \\
\hline Apon & 1.434 & 8 \\
\hline Kola (obi abata) & 1.400 & 9 \\
\hline Walnut & 1.388 & 10 \\
\hline Coconut & 1.359 & 11 \\
\hline Agbalumo & 1.347 & 12 \\
\hline Palm wine & 1.331 & 13 \\
\hline Alligator pepper & 1.272 & 14 \\
\hline Herbs & 1.256 & 15 \\
\hline Bush mango & 1.247 & 16 \\
\hline Chewing stick & 1.244 & 17 \\
\hline Bamboo & 1.228 & 18 \\
\hline Ginger & 1.213 & 19 \\
\hline Bread fruit & 1.203 & 20 \\
\hline Locust bean & 1.191 & 21 \\
\hline Mushroom & 1.181 & 22 \\
\hline Pearl & 1.175 & 23 \\
\hline Scent plant & 1.166 & 24 \\
\hline Raphia palm & 1.163 & 25 \\
\hline Breadfruit & 1.153 & 26 \\
\hline African guinea pepper & 1.153 & 26 \\
\hline Cheese & 0.138 & 27 \\
\hline Ropes & 0.134 & 28 \\
\hline Black pepper & 0.122 & 29 \\
\hline Garden egg & 0.122 & 29 \\
\hline Gum & 0.119 & 30 \\
\hline Luffa spp & 0.119 & 30 \\
\hline Tetrapleura tetraptera & 0.106 & 31 \\
\hline Honey & 0.100 & 32 \\
\hline Isin & 0.097 & 33 \\
\hline Coffee & 0.078 & 34 \\
\hline Spring onion & 0.063 & 35 \\
\hline Shear butter & 0.059 & 36 \\
\hline Rauvolla vomitora & 0.050 & 37 \\
\hline
\end{tabular}

Source: Field Survey, 2018 


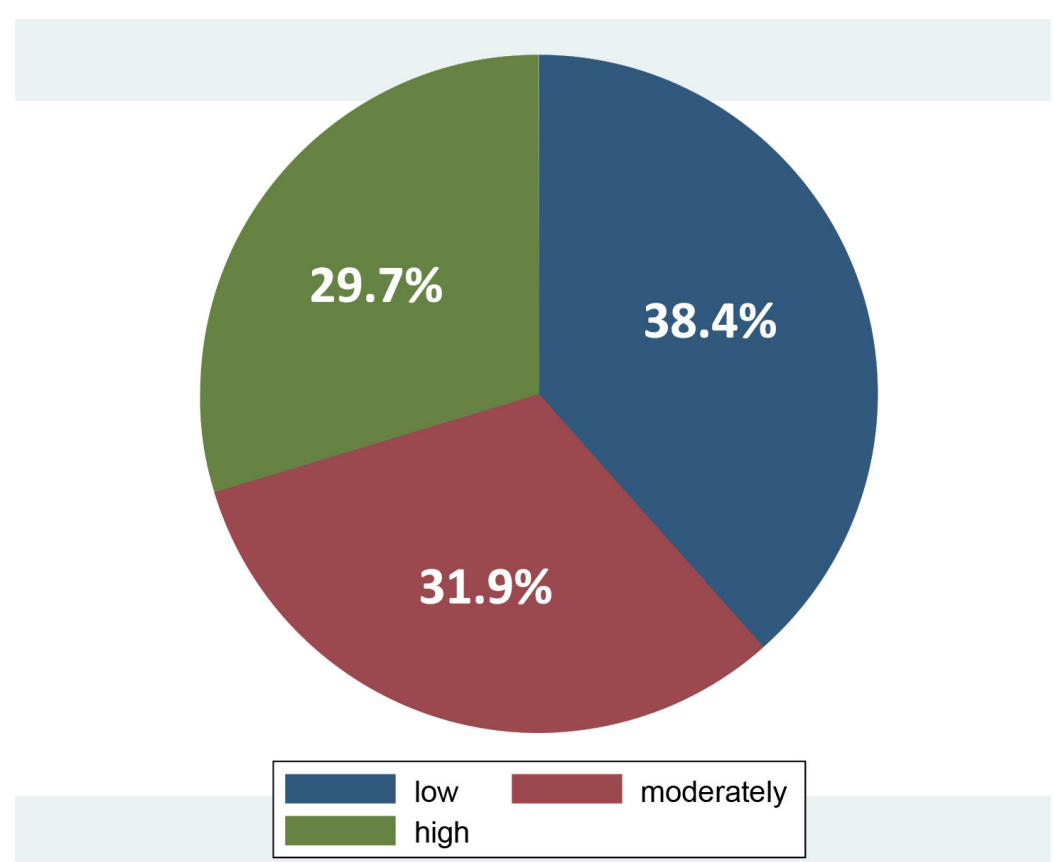

Mean=62.2, SD= 12.1, Low (score 50 or below); $n=126$, Moderate (score between 51 and 73); $\mathrm{n}=88$, High (score 74 and above); n=106; Source: Field survey, 2018

Figure 2 - Level of participation in the exploitation of NTFPs $(n=320)$

Willingness to continue in the exploitation of NTFPs

In order to further gauge the importance of NTFPs as a source of livelihood, respondents were asked whether or not they will continue to engage in NTFP business if there is an alternative source of income. Fig. 3 shows percentage distribution of respondents who will continue to exploit NTFPs, even if there is an alternative source of income according to forest zone.

All the respondents in AkureOfosu indicated their willingness to continue with their NTFP trade, even if they have alternative source of livelihood, compared with slightly more than half $(52.6 \%)$ of respondents in Oluwa forest zone, and at least $79.5 \%$ and $72.0 \%$ of those in Omo and Shasha forests.

Overall, $72.8 \%$ of the respondents said they will continue to engage in NTFP business, even when they are provided with other means of livelihood. This implies that majority of the respondents see exploitation of NTFP products as sustainable source of livelihood due to benefits they derive from their exploitation. 


\section{PARTICIPATION OF RURAL WOMEN IN EXPLOITATION OF NON-TIMBER FOREST PRODUCTS}

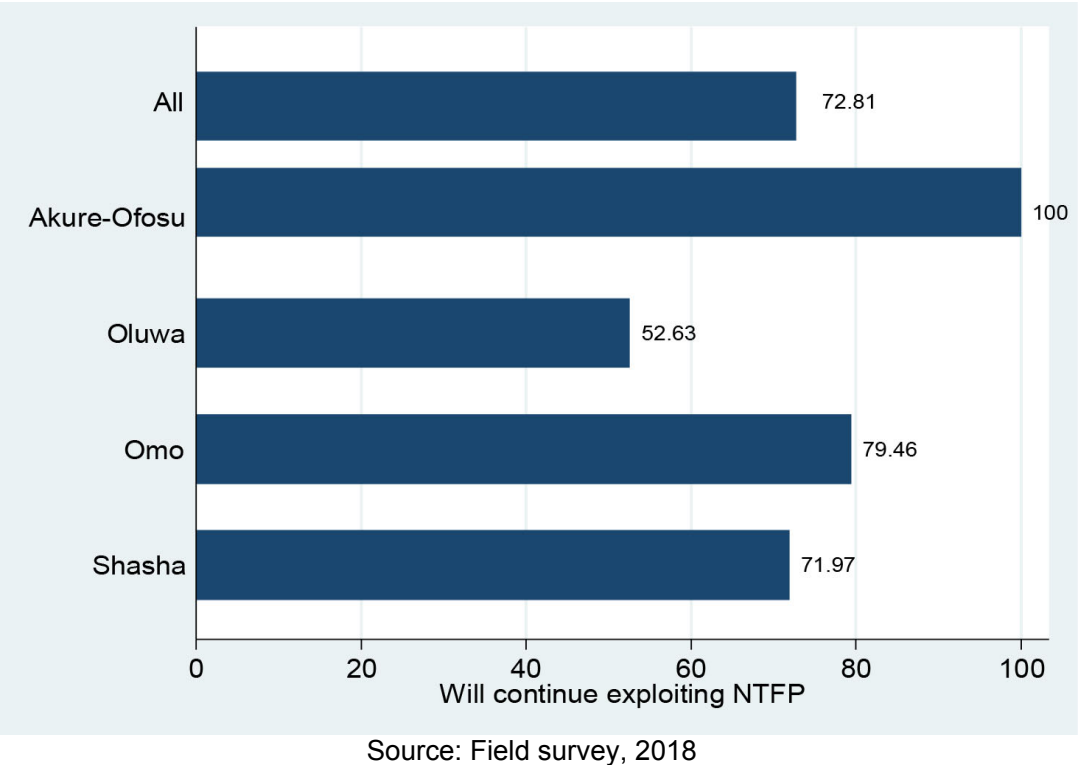

Figure 3 - Percentage distribution of respondents that will continue to exploit NTFP when there is other alternative

Regression analysis of the relationship between socioeconomic variables and participation in exploitation of NTFPs

Results in Table 3 show that overall, socioeconomic variables are significantly related to participation in exploitation of NTFPs. This is because the observed probability value associated with F-statistic of 8.72 is small $[\mathrm{F}(5,314)=8.72) ; p<0.01]$. Specifically, age of respondents (linearized) $\quad(\mathrm{t}=-2.39 ; \quad p<0.05)$, numbers of hours of collecting NTFPs per week $(\mathrm{t}=3.48 ; p<0.01)$, years of experience $(\mathrm{t}=-3.88 ; p<0.01)$ and external orientation $(\mathrm{t}=2.20 ; p<0.05)$ are significant predictors of participation in exploitation of NTFPs. In terms of relative importance of each of the independent variables on participation in exploitation of NTFPs as measured by the Beta coefficient, age of respondents is the most important predictor of participation in exploitation (Beta coefficient $=-0.926$ ).

The inverse relationship between age of respondents and participation in exploitation of NTFPs implies that lower the age of respondents is associated with higher participation in the exploitation of NTFPs. This suggests that younger respondents tend to be more involved in the exploitation of NTFPs than the older respondents. Next to age of respondents is the respondents' years of experience, number of hrs spent on collection of NTFPs and external orientation. Years of experience is also inversely related to participation 
in the exploitation of NTFPs, as depicted by Beta coefficient of -0.220 . This implies that the higher the number of years involved in exploitation, the lower the participation in exploitation of NTFPs and vice versa.

External orientation is positively related to participation in NTFPs, which suggests that the higher the frequency of travelling outside the community in relation to NTFP business, the higher the participation in NTFP exploitation. Similarly, the higher the number of hours spent on NTFP collection, the higher the participation in NTFP exploitation.

In all, the socioeconomic variables in the regression equation jointly explained at least $53 \%$ of the total variations in participation in exploitation of NTFPs, as depicted by the multiple coefficient of determination ( $\mathrm{R}$-squared $=53.15)$.

Table 3 - Regression analysis of the relationship between personal and socioeconomic variables and participation in exploitation of NTFPs

\begin{tabular}{llll}
\hline Variable & $\begin{array}{l}\text { Beta } \\
\text { coefficient }\end{array}$ & T & p-value \\
\hline Age of respondent & -0.926 & -2.39 & $0.018^{*}$ \\
\hline Number of dependants & -0.004 & -0.06 & 0.951 \\
\hline $\begin{array}{l}\text { Number of hours of collecting } \\
\text { NTFP per week }\end{array}$ & 0.189 & 3.48 & $0.001^{* *}$ \\
\hline Number of children & 0.032 & 0.51 & 0.614 \\
\hline Years of experience & -0.220 & -3.88 & $0.000^{* *}$ \\
\hline External orientation & 0.121 & 2.20 & $0.029^{*}$ \\
\hline Constant & & 3.72 & $0.000^{* *}$ \\
\hline
\end{tabular}

*Significant at $p<0.05$; ** significant at $p<0.01$; Number of observation=320; $\mathrm{R}=0.7291$; $\mathrm{R}$-squared=0.5315; Adjusted R-squared $=0.1079, \mathrm{~F}(5,314)=8.72) ; p=0.000$; Source: Calculated from Field survey, 2018

\section{CONCLUSIONS}

Based on the findings of this study, it was concluded that palm fruits, kolanut, bitter cola, vegetables, snails and fire wood ranked high among the NTFPs collected by the rural women in the study area. Also, participation in collection of NTFPs was moderate among the respondents. It is recommended that there is need for concerted efforts to encourage rural women for greater participation in exploiting NTFPs, as a means of livelihood because of varieties of benefits attached to it. Furthermore, more enlightenment programmes should be organized by the government for the rural women for awareness creation on the income generation opportunities that abound in the NTFPs sector.

\section{REFERENCES}

Adisa, B.O. \& Alao, O.T. (2011). Assessment of rural youths Involvement in the exploitation of 


\section{PARTICIPATION OF RURAL WOMEN IN EXPLOITATION OF NON-TIMBER FOREST PRODUCTS}

non-timber forest products in selected communities of Shasha Forest Reserves in South-West Nigeria. Age, 15(20): 21-26.

Aiyeloja, A.A. \& Ajewole, O.I. (2006). Non-timber forest products' marketing in Nigeria: A case study of Osun State. Educ.Res.Rev., 1(2): 52-58.

Akanni, K. A. (2013). Economic benefits of non-timber forest products among rural communities in Nigeria. Environ.Nat.Resour.Res., 3(4): 1926, DOI: 10.5539/enrr.v3n4p19

Amusa, T.O., Jimoh, S.O. \& Azeez, I.O. (2012). Determining the local importance of non-timber forest products using two different prioritization techniques, Int.J.Agric. For., 2(1): 84-92, DOI: 10.5923/j.ijaf. 20120201.14

Andel, T.V. (2006). Non-timber forest products, the value of wild plants, Agrodok- Series no. 39, Agromisa Foundation and CTA, Wageningen the Netherlands, pp. 7-17.

Angoni, H. (2015). Non-timber forest products and their contributions on the income of local residents in the Douala-Edea Wildlife reserve of Cameroon. J.Ecol.Nat.Environ., 7(10): 263-270, DOI: 10.5897/JENE 2015.0534

Bamiwuye, O.A. (2014). Factors influencing Rrle Ppance of community based organizations in rural dvelopment of Osun State, Nigeria. An Unpublished M.Sc. Thesis, Department of Agricultural Extension and Rural Development, Obafemi Awolowo University, Ile-Ife, Osun State, pp. 33-34.

Bisong, F.E. \& Ajake, A.O. (2001). An economic analysis of women's dependence on forest resources in the rain forest communities of southern Nigeria. Global J. Pure Appl.Sci., 7(2): 345-350, DOI: 10.4314/gjpas.v7i2.16254

Biswas, S.R. \& Choudhury, J.K. (2007). Forests and forest management practices in Bangladesh: the question of sustainability. Int.For.Rev., 9(2): 627-640, DOI: 10.1505/ifor.9.2.627

Carr, M. \& Hartl, M. (2008). Gender and non-timber forest productspromoting food security and economic empowerment. IFAD, http://www.ifad.org/gender/pub/timbe r.pdf

Chikamai, B.N. \& Kagombe, J. (2002). Country report for Kenya. In: Review and synthesis on the state of knowledge of Boswellia spp. and commercialisation of Frankincense in the drylands of Eastern Africa. KEFRI, Nairobi.

Dishan, E.E., Agishi, R. \& Akosim C. (2010). Women's involvement in non-timber forest products utilization in support zones of Gashaka Gumti National Park. J. Resources from Wild Environ., 2(1): 73-84.

Dovie, D.B.K. (2003). Rural economy and livelihoods from the non-timber forest products trade. Compromising sustainability in southern Africa?. Int.J.Sust.Dev. World, 10 (3): 247262, DOI: $10.1080 / 1350450030946$ 9803

Ellis, F. \& Allison, E. (2004). Livelihood diversification and natural resource access: Economic Planning Unit, Malaysia, 2010. Tenth Malaysia plan 2011-2015. Malaysia: Prime Minister's Department, Putrajaya.

Famakinwa, M. (2017). Factors influencing role performance of community in rural development activities in southwestern Nigeria. An Unpublished Ph.D thesis, Department of Agricultural Extension and Rural Development, Obafemi Awolowo University, p. 76

Fernande, A.N. \& Ghislaine, N.M.V. (2014). Women and non-timber forest product exploitation: the case of Prunus africana in the highlands of mount Cameroon. http://www.ijias. issr-journals.org/ accessed on 30th October, 2016 


\section{O.A. BAMIWUYE, B.O. ADISA, K.A. ADELOYE, M. FAMAKINWA}

Food and Agricultural Organization (FAO) (2012). State of the world's forests 2012, Rome.

Jimoh, S.O. \& Haruna, E. A. (2007). Contributions of non-timber forest products to Hhusehold food security and income around Onigambari Forest Reserve, Oyo State, Nigeria. J.Environ.Ext., 6: 28-33, DOI: 10.4314/jext.v6i1.2758

Jimoh, S.O., Amusa, T.O. \& Azeez, I.O. (2012). Prevalence, utilization and conservation strategies for nontimber forest products in south western zone of Nigeria. Resources and Environ., 2(1): 46-54, DOI: 10.5923/j.re.20120201.07

Ingram, V. (2009). The hidden costs and values of NTFP exploitation in the Congo Basin. In: 13th World Forestry Congress, 18-23 October 2009, Buenos Aires, Argentina.

National Bureau of Statistics (NBS) (2014). Nigerian Gross Domestic Product Report, Quarter 1, 2014 www.nigerianstat.gov.ng accessed on $14 / 08 / 2016$.

Ogunbanjo, O.O. \& Aina, A.S. (2013). Non-timbers forest products for poverty reduction in Ogun Waterside Local Government, Ogun State, Nigeria. J.Agric.Sci., 4(1): 49-53, DOI: $10.1080 / 09766898.2013 .1188$ 4701

Ogunjemite, B.G. \& Olaniyi, O.E. (2012). The chimpanzees of Oluwa Forest Reserve, southwest Nigeria", Int.J.Dev.Sustain., 1(3): 823-833.

Olaniyi, O.A., Akintonde, J.O. \& Adefumbi, S.I (2013). Contribution of non-timber Forest products to household Food security among rural women in Iseyin Local Government Area of Oyo State,
Nigeria. Res.Humanit.Soc.Sci., 3(7): 41-49.

Raufu, M.O., Akinniran T.N., Olawuyi, S.O. \& Akinpelu M.O. (2012). Economic analysis of rural women income from non-timber forest products in Ife South Local Government Area of Osun State, Nigeria. GJSFR, 12(1): 23-32.

Shackleton, C. \& Shackleton, S. (2004). The importance of non-timber forest products in rural livelihood security and as safety nets: a review of evidence from South Africa. S.Afr.J.Sci., 100(11-12): 658-664.

Sulaimon, S.W. (2016). Gender assessment of forest products utilization by rural dwellers in Osun State, Nigeria. Unpublished M.Sc.Thesis, Obafemi Awolowo University, Ile-Ife, Nigeria.

Suleiman, M.S., Wasonga, V.O., Mbau J.S., Suleiman, A. \& Elhadi, Y.A.(2017). Non-timber forest products and their contribution to households income around Falgore Game Reserve in Kano, Nigeria. Ecol.Process., 6(23): DOI: 10.1186/ s13717-017-0090-8

Vantomme, P., Markkula, A. \& Leslie, R.N. (2002). Non-wood forest products in 15 countries of tropical Asia: a regional and national overview. FAO Regional Office for Asia and the Pacific, Bangkok, 188 p.

Vongkhamsao, V. (2007). The role of NTFPs in poverty alleviation and biodiversity conservation. K. Warner, E. McCall and S. Garner (Eds.), Proceedings of the international workshop on the theme in $\mathrm{Ha} \mathrm{Noi}$, June 2007, $132 \mathrm{p}$. 